\title{
KARST, SCIENTIFIC UNCERTAINTY, AND THE LAW
}

Jesse J. Richardson, Jr.

West Virginia University College of Law, P.O. Box 6130, Morgantown, West Virginia 26506-6130,

jesse.richardson@mail.wvu.edu

\begin{abstract}
Courts struggle to deal with evidence relating to the existence of karst terrain and the impact of human activities on karst terrain. Although courts often must hear cases involving complex scientific issues, karst seems to prove especially problematic, perhaps because of the lack of uniformity and the site-specific nature of the resource.
\end{abstract}

Helping Others Maintain Environmental Standards (HOME) v. Bos, 406 Ill.App.3d 669, 941 N.E.2d 347 (2010) ("Bos"), represents the most extreme example of a court struggling with evidence relating to karst matters. The court found against the plaintiffs, primarily because the expert witness admitted that additional testing could have been done, but was not, due in part to financial constraints. One legal treatise referred to the defense's "relentless theme of studies not done" as "raging, fuming, "it's-all-an-environmental-conspiracy" presentation (Rogers Environmental Law, 2d., Section $4: 18)$. This case explicitly raises the questions that many others implicitly raise. How many studies are enough? Which studies are sufficient?

The Bos case and a variety of other published opinions involve courts analyzing expert testimony as to karst matters and determining whether such evidence is sufficient. Examination of these cases proves useful for future litigants and experts. The cases examined involve a variety of situations, including Environmental Impact Assessments and various citizen challenges to development. The review reveals that courts apply inconsistent standards and then use inconsistent analysis in the application. Some of the inconsistency can be explained by the context of the case, while others cannot.

Analysis of the court cases indicate that courts are generally ill-equipped to deal with expert testimony related to karst matters and that this testimony may prove to be more problematic than other technical, scientific evidence due to the nature of karst as a heterogeneous resource depending upon site-specific studies and examination. This circumstance further raises the issue of the cost of expert testimony relating to karst in court cases and whether karst investigations should instead be conducted by state or federal agencies. However, if these agencies should conduct the investigations, do the agencies have adequate resources to do so?
The paper recommends that the scientific karst community further educate lawyers, judges and citizens on the scientific aspects of karst, including the heterogeneous nature of karst. Ultimately, however, expert witnesses in karst matters will be forced to incorporate education of the court into their reports and testimony, to the extent that the court allows.

\section{Introduction}

Courts struggle to understand increasingly complex and technical expert testimony in a broad range of cases. However, nowhere is this struggle more evident than with respect to expert testimony related to karst. In 2010, a state court in Illinois decided a case that drew national attention for the court's extraordinary comments on expert witness testimony on a karst issue. The context of the case raises a number of issues on expert testimony, including how courts should evaluate the testimony, who should pay for expert testimony and whether experts must conduct every test possible. Examination of this case, along with the handful of additional court cases in the United States that evaluate expert testimony on karst, yields some basic principles that should guide expert witnesses and litigants in karst matters.

\section{The Nature of Expert Testimony}

The Federal Rules of Evidence set forth the guidelines for qualification as an expert witness and for evaluation of expert witness testimony in federal courts. An expert qualifies by knowledge, skill, experience, training or education (Federal Rules of Evidence Rule 702). Opinions expressed must meet the following requirements: (1) the expert's scientific, technical, or other specialized knowledge will help the trier of fact to understand the evidence or to determine a fact in issue; (2) the testimony is based on sufficient facts or data; (3) the testimony is the product of reliable principles and methods; and, (4) the expert has reliably applied the principles and methods to the facts of the case Federal Rules of Evidence Rule 702). An expert may base their opinion on facts and data personally observed or facts and data the witness has been made aware of (Federal Rules of Evidence Rule 703).

Rules that apply in most state courts are either based on or similar to the Federal Rules. Judges have fairly broad discretion in applying the rules. 
Another issue that proves important in understanding these issues involve the relationship between trial courts and appellate courts. Trial courts find the facts and then apply the law to the facts to make rulings. If a jury is seated, the jury finds the facts and the court instructs the jury on the law to apply. If no jury sits, the judge in the trial court finds the facts and applies the law. Appellate courts hear legal arguments and generally do not hear witnesses or admit additional evidence.

Therefore, appellate courts generally defer to the trial court, or the court that hears the testimony, on facts. Facts include judgements about expert testimony. The trial court is held to an "arbitrary and capricious" standard on factual issues. With respect to legal issues, the appellate court generally owes no deference to the trial court and may apply the law as the appellate court interprets the law.

\section{An Illinois Case Creates Uncertainty for Expert Testimony Introduction}

In Helping Others Maintain Environmental Standards v. Bos, 406 Ill.App.3d 669, 941 N.E.2d 347 (2010) ("Bos"), a citizen group (HOMES) filed suit against the developer of a large dairy facility and the Illinois Department of Agriculture to prevent the construction of the dairy. The citizen's group had an employee of the Illinois State Geological Survey, who was not paid by HOMES, testify as an expert witness on their behalf. The trial court ultimately ruled against HOMES. The case was appealed by HOMES. Most importantly for this analysis, the appellate court approved the trial court's holding that HOMES did not meet the requirements to obtain a permanent injunction.

Specifically, HOMES needed to demonstrate a high probability of groundwater contamination from the dairy. HOMES has an employee of the Illinois State Geological Survey testify as to the high probability. Bos' expert witnesses testified otherwise. The trial court found that HOMES failed to prove the high probability of groundwater contamination. The appellate court ruled that the trial court finding was reasonable and upheld the finding.

\section{Facts of the Case}

Bos proposed to build two large dairies, each of which would hold 6,850 animal units in the form of dairy cows and calves. One of the facilities would have three livestock waste holding ponds. To move forward, Bos needed approval from the Illinois Department of Agriculture. Eight siting requirements must be met to receive approval under the Illinois Livestock Act. The requirements ask whether:

(1) registration and livestock waste management plan certification requirements were met by the notice of intent to construct;

(2) the design, location, or proposed operation would protect the environment by being consistent with the Livestock Act;

(3) the location minimized incompatibility with the area's character by being zoned for agriculture or complying with the Livestock Act's setback requirements;

(4) the facility was in a 100-year flood plain or an environmentally sensitive area and, if so, whether the proposed construction standards were consistent with protecting the area's safety;

(5) the owner or operator submitted plans to minimize the likelihood of environmental damage from spills, runoff, and leaching;

(6) odor control plans were reasonable and incorporated odor reduction technologies;

(7) traffic patterns minimized the effect on existing traffic flow; and

(8) construction of the facility was consistent with community growth, tourism, recreation, or economic development through compliance with applicable zoning and setback requirements.

(510 ILCS 77/ 12(d)).

Requirement (4), which provides for heightened construction standards in karst areas, formed the focus of the case and the expert testimony. "Environmentally sensitive area" includes a karst area or an area with aquifer material within five feet of the bottom of the waste facility. Much of the dispute focused on whether the proposed facility was in a "karst area". The lawsuit alleged that the bedrock underlying the proposed facility and in the area of the facility consisted of Galena Group Carbonate Rock with karst features. These geologic conditions make the groundwater in the area highly susceptible to contamination according to the allegations. Specifically, the claims of HOMES centered on the issue of whether the waste containment pond liners were inadequately designed because the design failed to consider the karst terrain. 


\section{Karst Areas and Location of Livestock Waste Handling Facilities}

The Illinois Livestock Act defines "karst area" as "an area with a land surface containing sinkholes, large springs, disrupted land drainage, and underground drainage systems associated with karstified carbonate bedrock and caves or a land surface without those features but containing a karstified carbonate bedrock unit generally overlain by less than 60 feet of unconsolidated materials" (510 ILCS 77/10.24). "Karstified carbonate bedrock" is defined as "a carbonate bedrock unit (limestone or dolomite) that has a pronounced conduit or secondary porosity due to dissolution of the rock along joints, fractures, or bedding plains" (510 ILCS 77/10.26).

Under administrative regulations, if the "proposed livestock waste handling facility is to be located within an area designated as 'Sink hole areas' on 'Karst Terrains and Carbonate Rocks of Illinois', IDNR-ISGS Illinois Map 8"2, or if soil samples from within 20 feet of the livestock waste handling facility boundaries indicate that the waste handling facility is in a "karst area," additional inspections and tests are required (35 Ill. Adm. Code $\S \S$ 506.302(b), (g)). If a livestock waste handling facility is in a karst area, the waste facility must be designed to prevent seepage of waste into groundwater (510 ILCS 77/13(b)(2); 35 Ill. Adm.Code $\S 506.312(a))$ and is to be constructed using a rigid material such as concrete or steel (35 Ill. Adm.Code § 506.312(b)).

However, the facility's owner or operator may receive the Department's permission to "modify or exceed these standards in order to meet site specific objectives" (35 Ill. Adm. Code $\S 506.312(\mathrm{c})$ ). In such a situation, the owner or operator must demonstrate that the modification is at least as protective of the groundwater, surface water, and structural integrity of the waste facility as are the regulation's requirements (35 Ill. Adm. Code $\S 506.312(\mathrm{c}))$. No livestock waste facility may be constructed within 400 feet of a natural depression in a karst area (510 ILCS 77/13(b)(2); 35 Ill. Adm.Code § $506.302(\mathrm{~g})(1))$.

\section{The Expert Testimony}

The trial turned on the expert witnesses on each side. HOMES relied mainly on evidence presented by Samuel Panno. Panno is a senior scientist with the Illinois State Geological Survey. The state Attorney General's Office originally asked Panno to get involved in the case, presumably on behalf of the state (Bos, 374). The Attorney General's Office later changed their mind and decided that the state should not be involved (Ibid).
Panno testified that karstified carbonate bedrock was "a crucial component of [HOME's] case" (Bos, 374). Panno admitted that he failed to make a site-specific investigation. He based his opinion on LiDAR imagery, examination of aerial photos and field investigations. The testimony indicated that Panno used LiDAR imagery to locate fractures in the carbonate rock. One lineament underlain a waste holding pond, but Panno admitted that lineaments are an interpretative tool to indicate where to look for further information. One photo appeared to show a spring, but Panno admitted that he could not definitely identify the feature as a spring. The testimony failed to tie his findings directly to the site of the waste holding ponds, with the information mainly coming from outside the site (Ibid).

Panno similarly testified that elevated levels of sodium chloride could indicate susceptibility of the karst aquifer, but admitted that similar levels had been found in nonkarst areas. His investigation failed to include testing of wells near the dairy for bacteria. Panno admitted that such tests were a "good idea" to detect a connection between septic systems and the wells (Ibid).

Panno testified that Bos should have measured stream flow, performed groundwater chemistry evaluation, installed monitoring wells and conducted dye tracing, but he failed to take the same steps (Bos, 374). He admitted that a site-specific analysis would most appropriately determine the characteristics of the site. Panno also called into question the testimony of another expert who had suggested that the presence of weathered or highly weathered limestone in rock corings and borings indicated karstic bedrock. Panno stated that not all such bedrock is karstified carbonate bedrock.

The trial court also seemed to place great weight on Panno's admission that a number of additional tests could have been conducted to provide more definitive indications of whether karst terrain underlain the proposed dairy site. Specifically, Panno did not evaluate groundwater chemistry, conduct well monitoring or use dye tracing. Panno failed to take these steps due to cost (Ibid). The State Geological Survey had few resources and so various tests were not done (Bos, 375). He did not ask HOMES to fund the studies because that is "not something we do" (Ibid). The state funding was so limited that staff would "drive 10 hours round trip and do 10 hours of fieldwork in one day because there was no money to stay overnight in a hotel" (Ibid).

However, no rock corings from the site were examined and no bacterial well data from the area were sought. 
These tests would not be prohibitively expensive (Bos, 374). The court characterized HOMES' evidence as "vague" as to specific contaminants, concentrations and release mechanisms (Ibid).

The court placed greater weight on the evidence presented the expert witnesses for Bos. The court favorably cited the regional and site-specific investigations, including examination of rock corings and well data. The Bos experts concluded that the area was not karst and that facility design was sufficient to protect groundwater (Ibid). Bos also argued that certain information that Panno failed to disclose at the trial for the preliminary injunction entitled them to damages (Ibid).

\section{Conclusions}

Commentators reacted incredulously to the standard that the Bos case appeared to set. "The defense puts on a raging, fuming, "it's-all-an-environmental-conspiracy" presentation, and the court sits there meekly, absorbing every word of it. The relentless theme of studies not done...is of course the stuff of routine crossexamination" (Rodgers and Burleson, Section 4.18). The fact that Panno, a civil servant, served as the expert witness for the citizen group also raises the issue of whether state or federal agencies should provide neutral expert testimony. In addition, the case raises the question of whether "the "studies not done" should be assigned to the citizens or undertaken by the authorities themselves" (Ibid). However, if state or federal agencies should serve as experts for the courts, significant additional funding needs to be provided.

\section{Other Karst Expert Testimony Cases Introduction}

A handful of other published court opinions also address the standards for expert testimony in cases where karst plays an important role. These cases appear in a variety of contexts. Although none of the cases present holdings as dramatic or far-reaching as Bos, the opinions, cumulatively, present guidelines that expert witnesses and litigants should heed in future cases

\section{Terpstra v. Peterson 1999 WL 289283 (Ct. App. Minn. 1999)}

Terpstra challenged the approval of a conditional use permit for a covered hog feedlot and alleged that the granting of the permit was arbitrary and capricious. (Terpstra, 1). Terpstra contended that an Environmental Assessment Worksheet should have been completed. However, the Rice County Board of Commissions determined that an EAW was not necessary and voted to approve the permit. Terpstra presented maps from the
Geological Atlas of Rice County that indicated that the proposed feedlot would be in an area with a moderate risk of karst. (Terpstra, 3).

The board questioned the accuracy of the information, noting that the conclusions were based only on topographical features and that no soil samples or wells samples were collected or analyzed (Ibid). The board concluded that "no evidence exists which suggests that Far-Gaze Farms' proposal would endanger the health, safety and welfare of the county's citizens." (Terpstra, 3).

The court found that while the evidence may not have significant probative value, the evidence "suggests" that karst exists in the area. (Ibid). Therefore, the proposal may endanger the health, safety and welfare of the county's citizens. However, the court upheld the approval of the permit. Terpstra failed to present evidence on the accuracy of the Geological Survey maps, the degree of danger presented by karst or how likely sinkhole formation is in a karst area (Ibid). No evidence on the record showing the relationship between a "karst problem" and public health and safety (Ibid).

\section{Olmsted County Concerned Citizens v. Minnesota Pollution Control Agency, 2010 WL 4941663 (Ct. App. Minn. 2010) (unpublished)}

The Minnesota Pollution Control Agency (MPCA) decided not to require an Environmental Impact Statement (EIS) for a proposed ethanol facility. Olmsted County Concerned Citizens (OCCC) filed suit, claiming that the decision was arbitrary, capricious and not supported by the evidence. Public comments on the draft Environmental Assessment Worksheet included concerns about the karst geological features, data and modeling methodologies, and spills and emergency responses. (Olmsted County Concerned Citizens, 1).

After a public hearing before the MPCA Citizen's Board (the "Board"), the Board delayed its decision and asked the MPCA to prepare a set of findings that would require a limited-scope EIS on several issues including surface water and groundwater interactions in karst geological areas and the adequacy of a 30-day pump test to predict the quantity and quality of water in the karst geological areas (Ibid, 2). At a second hearing, after receiving further information, the MPCA Citizen's Board determined that the proposed ethanol plant did not have the potential for significant environmental effects and voted unanimously that an EIS was not required. OCCC filed suit. 
With respect to dye tracing tests, the MPCA maintained that the tests were not needed because of the groundwater protection provided by the design of the plant. In addition, no open or free draining karst features exist on the property to allow the introduction of dyes. Furthermore, the "intensive site investigations and geophysics work" at the site vitiated the need for dye tracing (Olmsted County Concerned Citizens, 4). As for leaks and spills in light of karst geology, the court found that the record contained significant information indicating that the site contained few karst characteristics. If fractures or cavities in the bedrock were encountered in the excavation stage, plans were in place to address the issues (Ibid, 10). Based on the evidence, the decision was not arbitrary and capricious and was backed by substantial evidence.

\section{Karst Environmental Education and Protection, Inc. v. Federal Highway Administration, 2011 WL 5301589 (U.S. Dist. Ct., W.D. Kentucky 2011)}

Karst Environmental Education and Protection, Inc. (KEEP) challenged the adequacy of the geologic survey relied on by the Federal Highway Administration (FHWA) as "cursory". (Karst Environmental Education and Protection, 18). The group argued the National Environmental Policy Act (NEPA) requires an in-depth karst analysis, including dye tracing and computer modeling of groundwater (Hoosier Envtl. Council, 1). The study here failed to discuss karst topography "as a whole", focusing only on the largest caves and sinkholes. (Karst Environmental Education and Protection, 18). KEEP also faulted the method by which the Final Environmental Impact Statement (FEIS) tabulated the biological impact on the caves. The FEIS measured the distance from the Project area to the mouth of the cave. KEEP maintained that, given the speed by which groundwater could move, proximity to the cave opening is immaterial. The network of underground streams and passageways are much closer to the project.

The court rejected the arguments, citing the relative scale and impact of the project in this case and the project in Hoosier Envtl. The project at issue creates a connector road 3.8 miles long, whereas Hoosier Envtl involved a highway of over 140 miles. (Karst Environmental Education and Protection, 19). While acknowledging that the agency "could have" done more, the court found that the FHWA took the required "hard look" at the kart issues, finding that the review was proportionate to the size of the action. (Ibid). "[P]racticability and reasonableness must be taken into account...to preserve the values and amenities of the natural environment" (Envtl. Defense Fund, 468).
In re Louisiana Energy Services, LP, 2010 WL 3969642 (Ct. App. New Mexico 2010) Citizens for Alternatives to Radioactive Dumping (CARD) objected to the granting of a groundwater discharge permit to Louisiana Energy Services, LP (Louisiana Energy). CARD appealed a ruling of the lower court that, among other things, found that CARD's proffered expert witness did not qualify as an expert on the matter before the court.

The expert, Dr. Richard Phillips, testified that he had a Ph.D. in geomorphology and that CARD had retained him seventeen days earlier to investigate the ground water hydrology in the immediate vicinity of the site (In re Louisiana Energy Services, LP, 1). Phillips submitted a report about karst aquifers at the Waste Isolation Pilot Plant (WIPP) site, sixty to seventy miles from the Louisiana Energy site. Based on a field investigation he conducted north of the Louisiana Energy site, Phillips concluded that the Louisiana Energy site was in a karst region.

Phillips based his finding primarily on a structural depression that holds water ephemerally, and Baker Spring, which holds water perennially. Phillips testified that the depression and Baker Spring were "telltale features of a karst terrain." His testimony indicated that the karstic formation would likely be affected by runoff from the site. Phillips admitted that he had spent only one day in the field to support his findings and that he failed to visit the Louisiana Energy site (Ibid).

Expert witnesses for Louisiana Energy contradicted Phillips's testimony, asserting that the karst-like features observed by Phillips could have been caused by human activity. (In re Louisiana Energy Services, LP, 2) These witnesses concluded that no karst existed on the site, that Baker spring was not related to the site and evidence of karst on the site would not affect the viability of their operations on the site due to the hydrology in the area, and the practices and protections on the site.

The trial court concluded that Phillips failed to qualify as an expert witness in this case (Ibid, 5). The key findings to support this ruling included Phillips's failure to visit the site and the fact that Phillips's conclusions were based on karst features on an unrelated site and study of another site sixty miles from the Louisiana Energy Services site (Ibid). Citing New Mexico Rules of Evidence, similar to Rule 702 of the Federal Rules of Evidence, the New Mexico Court of Appeals affirmed this ruling, finding that the trial court's ruling was not arbitrary and capricious (In re Louisiana Energy Services, $L P, 4-5)$. 


\section{Conclusions}

The four cases cited in this section involve karst expert testimony in a variety of contexts. However, the cases present consistent principles. As indicated by these cases, the courts generally defer to the administrative agency. To rebut the agency, evidence must be substantial and show serious error on behalf of the agency. Testimony should be based on a site-specific investigation, the findings should be specific, and the evidence should clearly link impacts to the existence of karst features.

The cases in this section do not extend as far as the Bos case in requiring expert witnesses to engage in any and all possible tests. However, In re Louisiana Energy Services, $L P$ represents a significant ruling in that the court disqualifies the expert witness. Noting the case indicates that the expert's credentials fell short. Instead, the expert was disqualified due to basing the opinion on secondary sources instead of a site-specific investigation. A more accurate analysis of the court's opinion would classify the ruling as disqualifying the opinion, not the expert. If the expert would have done a site-specific investigation, he would likely have qualified.

\section{Conclusions}

The Bos case appears to impose extraordinary requirements on expert witnesses by discrediting expert testimony for, among other things, failing to use every possible test to characterize the site. The ruling remains unprecedented. However, examination of other cases involving expert witnesses, along with the pertinent Federal Rules of Evidence, on karst matters yields useful principles for expert witnesses and litigants. The Federal Rules of Evidence require that the expert possess the requisite expertise, the testimony is based on "sufficient facts and evidence" and "the product of reliable principles and methods", and that these principles and methods are applied to the facts of the case.

The Bos case illustrates how onerous the burden of proof may be on a party challenging an agency finding. That case suggests that the challenger may have to conduct "every possible study". On the other hand, Karst Environmental Education and Protection explicitly stated that the agency "could have" done more, but upheld the agency's investigation as adequate to meet the agency's duty to take a "hard look".

Court interpretations of the rules give greater weight to expert testimony that is (1) based on site-specific investigations and data; (2) includes specific and precise analysis; and (3) clearly links the data to specific impacts. The Bos case additionally suggests that the expert conduct every possible test that may aid in the investigation, and may be interpreted to require costly, and even cost-prohibitive tests. However, no other court has gone that far.

The Bos case also raise troubling questions of whether the burden of providing expert testimony should be placed on private citizens, who will rarely be able to match corporate opponents, or whether state and federal agencies should be funded to give them the ability to provide unbiased evidence to courts. Obviously, the cost of retaining an expert witness may be an insurmountable burden to many citizen groups. To conduct "every possible study" would eliminate even more groups from participation in the judicial process.

Courts also appear to struggle to understand the complexities of expert testimony relating to karst issues. Expert witnesses and the litigants who employ them should keep these issues in mind. Judges and juries must be educated in order to comprehend and analyze expert witness testimony relating to karst.

\section{References}

35 Ill. Adm.Code $\S \S 506.302$ (Conway Greene CDROM June 2002).

35 Ill. Adm.Code $\S 506.312$ (Conway Greene CD-ROM June 2002).

510 ILCS 77/10.24 (West 2008).

510 ILCS 77/10.26 (West 2008).

510 ILCS 77/ 12(d) (West 2008).

510 ILCS 77/13 (West 2008).

Envtl. Defense Fund v. Tenn. Valley Auth., 492 F.2d 466, 468 (6th Cir.1974).

Federal Rules of Evidence Rule 702, 28 U.S.C.A. Rule 702. Testimony by Expert Witnesses.

Federal Rules of Evidence Rule 703, 28 U.S.C.A. Rule 703. Bases of an Expert's Opinion Testimony.

Helping Others Maintain Environmental Standards (HOME) v. Bos, 406 Ill.App.3d 669 (2010).

Hoosier Envtl. Council v. U.S. Dept. of Transp., No. 1:06-cv-1442-DFH-TAB, 2007 WL 4302642 (S.D.Ind. 2007).

In re Louisiana Energy Services, LP, 2010 WL 3969642 (Ct. App. New Mexico 2010).

Karst Environmental Education and Protection, Inc. v. Federal Highway Administration, 2011 WL 5301589 (U.S. Dist. Ct., W.D. Kentucky 2011).

Olmsted County Concerned Citizens v. Minnesota Pollution Control Agency, 2010 WL 4941663 (Ct. App. Minn. 2010) (unpublished).

Rodgers WH, Burleson R. Rogers. 2017. Environmental law. 2nd Ed. Eagan, MN: Thomson Reuters.

Terpstra v. Peterson, 1999 WL 289283 (Ct. App. Minn. 1999). 